\title{
Procaspase-3-activating compound 1 stabilizes hypoxia-inducible factor $1 a$ and induces DNA damage by sequestering ferrous iron
}

\author{
Feifei $\mathrm{Li}^{1,2,3}$, Aili Wei ${ }^{1,2,3}$, Lijuan Bư1, Long Long ${ }^{1,2}$, Wei Chen ${ }^{1,2}$, Chen Wang ${ }^{1,3}$, Changqi Zhao ${ }^{3}$ and Lili Wang ${ }^{1,2}$
}

\begin{abstract}
Procaspase-3-activating compound 1 (PAC-1) induces procaspase-3 activation via zinc chelation. However, whether PAC-1 employs other mechanisms remains unknown. Here we systematically screened for potent PAC-1 targets using 29 enhanced green fluorescent protein-labeled reporter cell lines and identified hypoxia-inducible factor 1a (HIF1a) and RAD51 pathways as PAC-1 targets. These results were verified in HepG2 cells and two other cancer cell lines. Mechanistically, PAC-1 specifically blocked HIF1a hydroxylation and upregulated HIF1a target genes. In addition, DNA damage, $G_{1} / S$ cell cycle arrest, and the inhibition of DNA synthesis were induced following PAC-1 administration. Interestingly, by using ferrozine-iron sequestration and iron titration assays, we uncovered the iron sequestering capacity of PAC-1. Additionally, the expression levels of iron shortage-related genes were also increased in PAC-1treated cells, and iron (II) supplementation reversed all of the observed cellular responses. Thus, our results indicate that PAC-1 induces HIF1a stabilization and DNA damage by sequestering ferrous iron.
\end{abstract}

\section{Introduction}

Escaping apoptosis represents one of the hallmarks of cancer, and the induction of apoptotic cell death is a rational anticancer strategy. However, the dysregulation of apoptotic mechanisms and overexpression of antiapoptotic proteins often limit the efficacy of apoptosisinducing agents ${ }^{1}$. The discovery of procaspase-3activating compound 1 (PAC-1) may overcome this limitation. By activating procaspase- 3 to generate caspase-3, the main apoptosis effector, PAC-1 bypasses the complex upstream pro-apoptotic signaling cascades and directly

\footnotetext{
Correspondence: Changqi Zhao (04020@bnu.edu.cn) or Lili Wang (wangll63@126.com)

'Beijing Institute of Pharmacology and Toxicology, State Key Laboratory of Toxicology and Medical Countermeasures, Beijing 100850, China

${ }^{2}$ State Key Laboratory of Functions and Applications of Medicinal Plants, Guizhou Medical University, Guiyang 550014, China

Full list of author information is available at the end of the article.

These authors contributed equally: Feifei LI, Aili WEI.

Edited by A Finazzi-Agrò.
}

induces apoptotic cell death ${ }^{2}$. Procaspase-3 activators have since attracted much attention, and a series of compounds targeting procaspase- 3 have been discovered $^{3-7}$. However, the first report describing PAC-1 did not address the mechanisms underlying procaspase- 3 activation, and these still remain unclear to date ${ }^{8}$. Hergenrother and co-workers reported that PAC-1 activates procaspase- 3 by chelating the zinc ions required for its activity ${ }^{9}$. Although this mechanism has been widely accepted, it might not account for the full function of PAC-1. Moreover, the antitumor effect of PAC-1 has not been so far validated in humans.

In this study, we aimed to further elucidate the mechanisms underlying PAC-1 function. To this end, we analyzed the effects of PAC-1 on 29 pathways/proteins using enhanced green fluorescent protein (EGFP)-labeled reporter cell lines (Table 1). We then further investigated

\section{(c) The Author(s) 2018}

(c) (i) Open Access This article is licensed under a Creative Commons Attribution 4.0 International License, which permits use, sharing, adaptation, distribution and reproduction in any medium or format, as long as you give appropriate credit to the original author(s) and the source, provide a link to the Creative Commons license, and indicate if changes were made. The images or other third party material in this article are included in the article's Creative Commons license, unless indicated otherwise in a credit line to the material. If material is not included in the article's Creative Commons license and your intended use is not permitted by statutory regulation or exceeds the permitted use, you will need to obtain permission directly from the copyright holder. To view a copy of this license, visit http://creativecommons.org/licenses/by/4.0/. 
Table 1 The main information of signal pathways used in screening

\begin{tabular}{|c|c|c|c|c|}
\hline Targets or pathways & Cell lines & Compound incubation time & Mode of analysis & $Z^{\prime}$ factor \\
\hline AKT & Akt1-EGFP_CHO & $4 \min$ & Membrane translocation ${ }^{a}$ & $0.68 \pm 0.09$ \\
\hline$A R$ & AR-EGFP_U2OS & $6 \mathrm{~h}$ & Nuclear foci formation ${ }^{b}$ & $0.63 \pm 0.02$ \\
\hline ATF6 & ATF6-EGFP_U2OS & $5 \mathrm{~h}$ & Nuclear translocation ${ }^{c}$ & $0.58 \pm 0.09$ \\
\hline BTK & Btk-EGFP_CHO & $4 \mathrm{~min}$ & Membrane translocation & $0.74 \pm 0.11$ \\
\hline CBR1 & CBR1-EGFP_U2OS & $2 \mathrm{~h}$ & Internalization $^{d}$ & $0.55 \pm 0.21$ \\
\hline ERa & ERa-EGFP_U2OS & $20 \mathrm{~h}$ & Nuclear foci formation & $0.67 \pm 0.08$ \\
\hline FSHR & rFSHR-EGFP_U2OS & $2 \mathrm{~h}$ & Internalization & $0.57 \pm 0.06$ \\
\hline GLP-1R & GLP1R-EGFP_U2OS & $1 \mathrm{~h}$ & Internalization & $0.76 \pm 0.04$ \\
\hline GLUT4 & GLUT4-EGFP_CHO & $5 \mathrm{~min}$ & Membrane translocation & $0.49 \pm 0.12$ \\
\hline Hif1a & Hif1a-EGFP_CHO & $3 \mathrm{~h}$ & Nuclear accumulation ${ }^{e}$ & $0.55 \pm 0.10$ \\
\hline JAK/STAT1 & STAT1-EGFP_U2OS & $1 \mathrm{~h}$ & Nuclear translocation & $0.85 \pm 0.05$ \\
\hline JAK/STAT3 & STAT3-EGFP_BHK & $0.5 \mathrm{~h}$ & Nuclear translocation & $0.64 \pm 0.08$ \\
\hline M3/NFATc1 & M3:NFATc1-EGFP_U2OS & $20 \mathrm{~min}$ & Nuclear translocation & $0.74 \pm 0.10$ \\
\hline NF-KB & p65-EGFP_CHO & $40 \mathrm{~min}$ & Nuclear translocation & $0.50 \pm 0.12$ \\
\hline p27 ubiquitination & SCF-Skp2 E3 Ligase: p27-EGFP_HeLa & $24 \mathrm{~h}$ & Nuclear translocation & $0.82 \pm 0.08$ \\
\hline p38 MAPK & MAPKAPK2-EGFP_BHK & $1.5 \mathrm{~h}$ & Nuclear translocation & $0.56 \pm 0.09$ \\
\hline p53 ubiquitination & E6-AP: p53-EGFP_HeLa & $24 \mathrm{~h}$ & Nuclear accumulation & $0.81 \pm 0.05$ \\
\hline $\mathrm{p} 53-\mathrm{Hdm} 2$ & p53-Hdm2-EGFP_CHO & $2 \mathrm{~h}$ & Nuclear translocation & $0.63 \pm 0.01$ \\
\hline PI3K-FKHR & FKHR-EGFP_U2OS & $1 \mathrm{~h}$ & Nuclear translocation & $0.66 \pm 0.05$ \\
\hline PI3K-FKHRL1 & FKHRL1-EGFP_U2OS & $1 \mathrm{~h}$ & Nuclear translocation & $0.59 \pm 0.07$ \\
\hline PI3K-Foxo4 & Foxo4-EGFP_U2OS & $1 \mathrm{~h}$ & Nuclear translocation & $0.58 \pm 0.10$ \\
\hline PI3K-PDK1 & PDK1-EGFP_CHO & $2 \min$ & Membrane translocation & $0.73 \pm 0.12$ \\
\hline PKA & PKAcat-EGFP_CHO & $5 \min$ & Foci formation in cytoplasm ${ }^{f}$ & $0.67 \pm 0.08$ \\
\hline PKC $\beta$ & PKC $\beta$-EGFP_U2OS & $0 \mathrm{~min}$ & Membrane translocation & $0.28 \pm 0.05$ \\
\hline$P R$ & PR-EGFP_U2OS & $30 \mathrm{~min}$ & Nuclear foci formation & $0.43 \pm 0.05$ \\
\hline Rad51 & Rad51-EGFP_SW480 & $24 \mathrm{~h}$ & Nuclear foci formation ${ }^{c}$ & $0.73 \pm 0.10$ \\
\hline Ras-Raf & Raf-EGFP_CHO & $5 \mathrm{~min}$ & Membrane translocation & $0.54 \pm 0.09$ \\
\hline S1P1 & S1P 1 -EGFP_U2OS & $1 \mathrm{~h}$ & Internalization ${ }^{\mathrm{e}}$ & $0.83 \pm 0.03$ \\
\hline TGF $\beta-S m a d 2$ & Smad2-EGFP_CHO & $1 \mathrm{~h}$ & Nuclear translocation & $0.52 \pm 0.14$ \\
\hline
\end{tabular}

${ }^{a}$ Membrane translocation indicate EGFP-labeled proteins translocate from the cytoplasm onto the cell membrane. This analysis mode analyses the amount of EGFP patch on the cell membrane

${ }^{b}$ Nuclear foci formation indicate EGFP-labeled proteins form foci inside the nucleus. This analysis mode analyses the amount of EGFP foci inside the nucleus

${ }^{c}$ Nuclear translocation indicate EGFP-labeled proteins translocate from cytoplasm into the nucleus or simply accumulation in the nucleus. This analysis mode analyses the EGFP intensity in the nucleus

${ }^{d}$ Internalization indicate EGFP-labeled proteins translocate from cell membrane into cytoplasm

eNuclear accumulation indicate EGFP-labeled proteins appears and accumulation in the nuclear after positive compound treatment

fFoci formation in cytoplasm means translocation of PKAcat-EGFP from cytoplasmic aggregates to a uniform cytoplasmic localization

the mechanisms of PAC-1 on the hypoxic response and DNA damage in cancer cells.

\section{Materials and methods \\ Cell culture}

Fluorescently labeled reporter cell lines were purchased from Thermo Fisher Scientific (Waltham, MA), except for SMAD2-EGFP_CHO, MAPKAPK2-EGFP_BHK, and AKT1-EGFP_CHO, which were purchased from GE Healthcare (Fairfield, CT). All cell lines were cultured following the manufacturer's recommendation. The human hepatic carcinoma cell line HepG2 was purchased from the Type Culture Collection of the Chinese Academy of Sciences (Shanghai, China), and 
cultured in RPMI 1640 medium supplied with $10 \%$ fetal bovine serum.

\section{Compounds and reagents}

PAC-1, BP (2,2'-dipyridyl, a well-known iron (II) chelator and chemical hypoxia mimic), MG132, and ferrozine were purchased from Sigma-Aldrich (St. Louis, MO). Other reagents and all cell culture media were purchased from Thermo Fisher unless specifically stated. Primary antibodies targeting pH2AX (cat. no. H10292) and BrdU and labeled secondary antibodies were obtained from Life Technologies (Beverly, MA). Primary antibodies targeting hypoxia-inducible factor $1 \alpha$ (HIF1 $\alpha$; cat. no. ab16066) and Pro564 hydroxylated HIF1 $\alpha$ (cat. no. 3434) were purchased from Abcam (Cambridge, MA) and Cell Signaling Technology (Danvers, MA), respectively.

\section{Immunofluorescence staining for high-content analysis}

Immunofluorescence staining for $\mathrm{pH} 2 \mathrm{AX}$, HIF $1 \alpha$, $\mathrm{HIF} 1 \alpha-\mathrm{OH}$, and BrdU was conducted as described below. Briefly, cells were plated in Corning 3603 plates (blackwall, clear bottom 96-well plates; cat. no. 3603; Corning, Corning, NY), treated with different compounds, fixed with $4 \%$ formaldehyde, and washed twice with $1 \times$ phosphate-buffered saline (PBS). After permeabilizing the cell membranes using $0.1 \%$ Triton X-100 and blocking with $10 \%$ bovine serum albumin, target proteins were visualized using primary antibodies and fluorescently labeled secondary antibodies. Cell nuclei were labeled with $1 \mu \mathrm{M}$ Hoechst 33342 and subjected to image acquisition on an high-content analysis (HCA) platform.

\section{HCS for signaling pathways or target proteins}

Twenty-nine genetically modified reporter cell lines were used in cell-based signaling pathway or target protein screening. For each cell line, we followed the screening procedures recommended by the manufacturer; key information is briefly described in Table 1 . The concentrations of PAC-1 used for screening were 3 and 30 $\mu \mathrm{M}$. Detailed information regarding the RAD51 and HIF $1 \alpha$ assays is provided below. In order to display the screening results more intuitively, heat map was made basing on preliminary screening data using $\mathrm{MeV}$ software.

HIF1 $\alpha$-EGFP_CHO cells (CHO cells stably expressing the HIF1 $\alpha$-EGFP fusion protein) or RAD51EGFP_SW480 cells (SW480 cells stably expressing the RAD51-EGFP fusion protein) were seeded in Corning 3603 plates at a density of $8 \times 10^{3}$ cells/well for 24 or $48 \mathrm{~h}$ to allow adhesion. Then, different concentrations of PAC1 were added and the plates were incubated for 3 or $24 \mathrm{~h}$. Finally, cells were fixed with $4 \%$ formaldehyde, and the nuclei were dyed with $1 \mu \mathrm{M}$ Hoechst 33342 for $30 \mathrm{~min}$ at $37^{\circ} \mathrm{C}$. The cells were then subjected to high-content image acquisition and analysis using an IN CELL Analyzer
1000 platform. The activity of PAC-1 in HIF1 $\alpha$ pathway assays was expressed as the activation rate relative to that of the positive compound $(100 \mu \mathrm{M} \mathrm{BP})$ and negative control (0.2\% dimethylsulfoxide [DMSO]). The activity of PAC-1 in RAD51 pathway assays was expressed as the activation rate relative to that of the positive compound (10 $\mu \mathrm{M}$ camptothecin) and negative control (0.2\% DMSO) for screening and as the fold change of RAD51 intensity relative to the negative control $(0.2 \% \mathrm{DMSO})$ for $\mathrm{EC}_{50}$ testing.

\section{BrdU incorporation for HCA}

BrdU incorporation assays were performed using ClickiT EdU HCS Assays (Invitrogen, Thermo Fisher Scientific). Briefly, HepG2/U2OS cells were plated in Corning 3603 plates at a density of $1 \times 10^{4}$ or $9 \times 10_{3}$ cells/well, respectively, and cultured for $24 \mathrm{~h}$ before exposure to PAC- 1 for $3 \mathrm{~h}$. Next, $100 \mu \mathrm{L}$ BrdU $(20 \mu \mathrm{M})$ was added, and cells were incubated for another $4 \mathrm{~h}$ to allow BrdU incorporation into the newly synthesized DNA. Cells were then fixed, and the incorporated BrdU was labeled with Alexa Fluor 555. Cell nuclei were dyed with HCS Nuclear Mask Blue stain. Finally, cells were used for high-content image acquisition and analysis using the IN CELL platform. The inhibition of DNA synthesis by PAC-1 was expressed as the rate of change in BrdU-positive cells and the mean fluorescence intensity of BrdU-Alexa Fluor in each cell.

\section{High-content image acquisition and analysis}

Fluorescence images were all acquired with an IN CELL Analyzer 1000/2000 (GE Healthcare) under a $\times 10$ objective lens except that in supplement Fig. 6, as reported previously ${ }^{10,11}$. At least five fields and more than 500 cells/well were analyzed using the Multi Target Analysis Module of the IN CELL Analyzer Workstation 3.5. Each treatment was repeated in triplicate, and each experiment was repeated at least three times to ensure the robustness and reliability of the results.

\section{Flow cytometric cell cycle analysis}

Flow cytometric cell cycle analysis was conducted according to generally accepted procedures ${ }^{12}$. Briefly, HepG2 cells were harvested and fixed with $70 \%$ ethanol overnight after $24 \mathrm{~h}$ of PAC-1 exposure. Cells were then washed three times with PBS and treated with $50 \mu \mathrm{g} / \mathrm{mL}$ RNase at $37^{\circ} \mathrm{C}$ for $30 \mathrm{~min}$. Finally, cells were labeled with propidium iodide and analyzed with a FACSCalibur instrument (BD Biosciences, MA, USA).

\section{Quantitative polymerase chain reaction}

HepG2 cells were exposed to the compounds under normoxic or hypoxic conditions (1\% oxygen) for the indicated times. Total RNA was extracted using a BioTeke 
Table 2 The primers used in quantitative real-time PCR

\begin{tabular}{|c|c|c|}
\hline & Sense & Antisense \\
\hline Hif1a & 5'-CTCAAAGTCGGACAGCCTCA-3' & 5'-CCCTGCAGTAGGTTTCTGCT-3' \\
\hline VEGFA & 5'-CTTGCCTTGCTGCTCTACC-3' & 5'-CACACAGGATGGCTTGAAG-3' \\
\hline EPO & 5'-ACCAACATTGCTTGTGCCAC-3' & 5'-TCTGAATGCTTCCTGCTCTGG-3' \\
\hline TfR1 & 5'-ACTTGCCCAGATGTTCTCAG-3' & 5'-GTATCCCTCTAGCCATTCAGTG-3' \\
\hline DMT1 & 5'-TGTTTGATTGCACTGGGCATG-3' & 5'-CTGTCAGCAGGCCTTTAGAG-3' \\
\hline$\beta$-actin & 5'-TAAAGACCTCTATGCCAACACAGT-3' & 5'-CACGATGGAGGGGCCGGACTCATC-3' \\
\hline
\end{tabular}

Total RNA Extraction Kit (cat. no. RP1201; BioTeke, Beijing, China). RNA was then reverse transcribed into single-stranded cDNA using TransScript SuperMix (cat. no. AT311-03; TransGen, Beijing, China). The resulting cDNA was used as a template for quantitative polymerase chain reaction (qPCR). The primers used in this study are listed in Table 2. qPCR was conducted using the ABI PRISM 7900 sequence detection system (Applied Biosystems, Foster City, CA), as previously described ${ }^{13}$. The relative change in mRNA levels was determined using the $2^{-\Delta \Delta C T}$ method, and $\beta$-actin was used as the internal standard.

\section{Western blotting}

Cells were lysed after the indicated treatments. Approximately, $5 \mathrm{mg}$ of total protein for each sample were separated by sodium dodecyl sulfate polyacrylamide gel electrophoresis on $10 \%$ gels and then transferred to polyvinylidene difluoride membranes. The membranes were blocked with $5 \%$ fat-free milk and incubated with appropriate primary antibodies at $4{ }^{\circ} \mathrm{C}$ overnight, followed by incubation with horseradish peroxidase-conjugated secondary antibodies at room temperature for $1 \mathrm{~h}$. The immunostaining signals were visualized using the ECL plus reagent (Applygen, Beijing, China), imaged, and analyzed with an Alpha Imager 5500 (Alpha Innotech, San Leandro, CA).

\section{Ferrozine-iron (II) chelation assay}

The iron (II)-chelating activity of PAC-1 was assessed as previously described ${ }^{17}$, under nitrogen. Briefly, $19.6 \mathrm{~mL}$ double-distilled water (DDW) and $400 \mu \mathrm{L}$ of $0.2 \mathrm{mM}$ $\mathrm{FeCl}_{2}$ (final concentration $4 \mu \mathrm{M}$ ) were premixed, and an aliquot of $198 \mu \mathrm{L}$ was added into each well of a 96-well plate (Corning 3599). Next, $2 \mu \mathrm{L} /$ well of $100 \times$ drugs in DMSO were added. The plate was shaken on a microplate shaker for $5 \mathrm{~min}$ and incubated for $30 \mathrm{~min}$ to allow for equilibration. Next, ferrozine (final concentration 200 $\mu \mathrm{M})$ was added, and the plate was shaken on a microplate shaker for $10 \mathrm{~min}$. Finally, the absorbance at $550 \mathrm{~nm}$ was scanned using a SpectraMax M5 instrument (Molecular
Devices, Eugene, OR). The signal for control group 1, which contained only DDW and ferrozine, was set as $100 \%$ iron chelation, whereas the signal for control group 2, which contained DDW, $\mathrm{FeCl}_{2}$, and ferrozine, was set as $0 \%$ chelation. The chelation rate for the treatment groups was calculated as follows:

$$
\begin{aligned}
& \mathrm{CR}= \\
& \left(\mathrm{OD}_{\text {treatment }}-\mathrm{OD}_{\text {control2 }}\right) /\left(\mathrm{OD}_{\text {control1 }}-\mathrm{OD}_{\text {control2 }}\right) \times 100 \%
\end{aligned}
$$

\section{Iron (II) titration assay}

The titration of PAC-1 using Fe(II) or $\mathrm{Zn}$ (II) was conducted as previously described ${ }^{9}$ in buffer A $(50 \mathrm{mM}$ HEPES, $100 \mathrm{mM} \mathrm{KNO}$, $\mathrm{pH}$ 7.2) under nitrogen. Briefly, the absorbance spectrum of PAC-1 in $3 \mathrm{~mL}$ buffer A (final concentration $50 \mu \mathrm{M}$ ) from 230 to $500 \mathrm{~nm}$ was scanned using a SpectraMax M5 (Molecular Devices). Then, $1.5 \mu \mathrm{L}$ of $10 \mathrm{mM} \mathrm{FeCl}_{2}$ (or $\mathrm{ZnSO}_{4}$ ) were added to the system, and the absorbance spectrum was scanned again. The last two processes were repeated 15 times until the concentration of $\mathrm{FeCl}_{2}$ in the system reached $75 \mu \mathrm{M}$.

\section{Iron supplementation assays}

The effects of iron supplementation on the PAC-1induced formation of RAD51 foci, H2AX phosphorylation, and HIF1 $\alpha$ accumulation were examined. PAC-1 and $\mathrm{FeCl}_{2}$ (or $\mathrm{ZnSO}_{4}$ in HIF1 $\alpha$ accumulation assays) were added sequentially to the cell culture medium and incubated for the indicated duration.

The effects of iron supplementation on the antiproliferative activity of PAC-1 were also examined. HepG2 cells plated in 96-well plates were exposed to PAC-1 or PAC-1 plus $\mathrm{FeCl}_{2}$ for $48 \mathrm{~h}$. The nuclei were then labeled with $1 \mu \mathrm{M}$ Hoechst 33342 for 30 min before image acquisition using an IN CELL Analyzer 1000, and the cell counts for the different treatment groups were analyzed.

\section{Iron rescue assay}

HepG2 cells plated in 96-well plates were exposed to 30 $\mu \mathrm{M}$ PAC- 1 for $24 \mathrm{~h}$. At $0,0.5,1,2$, 4, or $6 \mathrm{~h}$ after PAC-1 addition, $30 \mu \mathrm{M} \mathrm{FeCl}$ was added. After $24 \mathrm{~h}$ of PAC-1 
treatment, nuclei were labeled with $1 \mu \mathrm{M}$ Hoechst 33342, and the cell counts for the different treatment groups were analyzed using an IN CELL Analyzer 1000.

\section{Data processing}

All data were processed with Microsoft Excel (2010) and reported as means \pm standard deviations. Concentration-effect curves were drawn, and the $\mathrm{EC}_{50}$ values were calculated using the GraphPad Prism 5 software. The statistical analysis was conducted using a oneway analysis of variance in SPSS 13.0 and Tukey tests for post hoc multiple comparisons. Differences with $P$ values of $<0.05$ were considered significant.

\section{Results}

\section{Screening of multiple signaling pathways}

To comprehensively investigate the effects of PAC- 1 on multiple signaling pathways or target proteins, an unbiased screening assay was conducted using HCA and 29 EGFP-labeled reporter cell lines representing different signaling pathways or targets. The $Z^{\prime}$ factor for almost all assays was $>0.5$ (Table 1 ), indicating that these cellular models were eligible for high-content screening (HCS) and that the screening system was reliable. As shown in Fig. 1, a 3 or $30 \mu \mathrm{M}$ concentration of PAC-1 did not affect the majority of signaling pathways or target proteins, except for the RAD51 and HIF1 $\alpha$ pathways. In the two positive cell lines, PAC-1 showed significant concentration-dependent effects, including the nuclear translocation of HIF $1 \alpha$ and the formation of RAD51 nuclear foci. Moreover, a $30 \mu \mathrm{M}$ dose of PAC-1 induced a similar effect to the maximum effect observed with 100 $\mu \mathrm{M}$ of BP in HIF $1 \alpha$ assays and approximately half that observed in the presence of $10 \mu \mathrm{M}$ of camptothecin in RAD51 assays. These screening results indicate that PAC1 selectively acts on the HIF1 $\alpha$ and RAD51 signaling pathways.

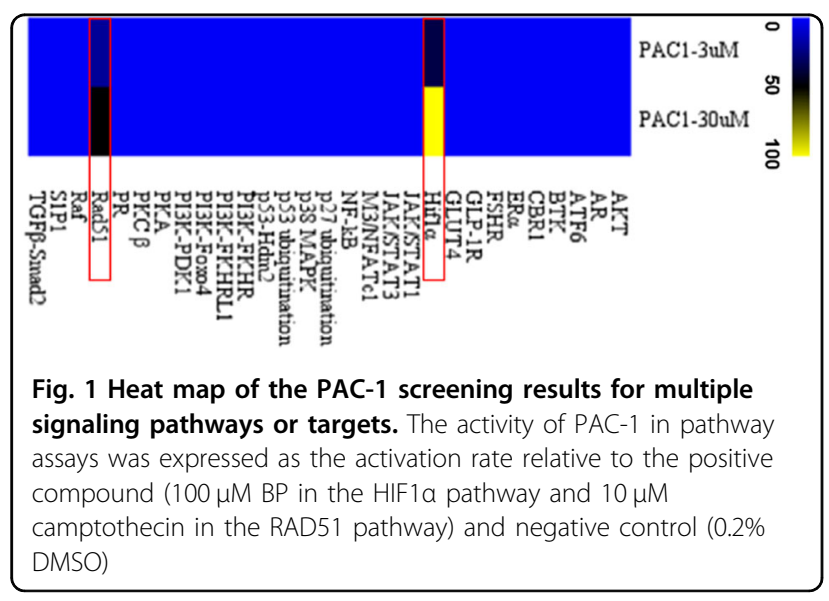

\section{PAC-1 induces HIF1a stabilization under normoxic conditions}

To further examine the effects of PAC-1 on HIF1 $\alpha$ in HIF1 $\alpha$-EGFP_CHO cells, a series of concentrations of PAC1 and the chemical hypoxia mimic BP (the well-known iron (II) chelator) were used, and the time-dependent effects following treatment with PAC-1 or BP were evaluated. As shown in Fig. 2a, considerable HIF1 $\alpha$ fluorescence was observed in the nucleus after $3 \mathrm{~h}$ of BP or PAC-1 treatment when compared with that in the untreated control group. A quantitative analysis of the HIF $1 \alpha$ fluorescence intensity showed that PAC-1 induced HIF1 $\alpha$ accumulation in a concentration-dependent manner (Fig. 2b). The calculated $\mathrm{EC}_{50}$ value was $3.96 \mu \mathrm{M}$, which was lower than that of $\mathrm{BP}$. The kinetics of HIF1 $\alpha$ accumulation indicated that PAC-1 could induce HIF1 $\alpha$ accumulation after only $0.5 \mathrm{~h}$ of PAC- 1 exposure and that the HIF $1 \alpha$ protein levels continued to increase until reaching a plateau after about $6 \mathrm{~h}$ of PAC-1 exposure, similar to our BP results (Fig. 2c). Moreover, this property of PAC-1 was not restricted to genetically modified HIF1 $\alpha$-EGFP reporter cell lines, as a concentrationdependent increase in HIF1 $\alpha$ protein levels was also observed in PAC-1-treated HepG2 cells (Fig. 2d-f), with an $\mathrm{EC}_{50}$ of $18.5 \pm 0.07 \mu \mathrm{M}$. Additionally, a $3 \mathrm{~h} \mathrm{PAC}-1$ treatment had no effect on cell counts and nuclear shape at the corresponding concentrations (Fig. 2e). These results indicate that PAC-1 induces HIF1 $\alpha$ accumulation under normoxic conditions, independent of cellular cytotoxicity.

\section{PAC-1 induces the accumulation of functional HIF1a by inhibiting HIF1a hydroxylation}

HIF1 $\alpha$ has a short half-life and is constitutively expressed in cells. Additionally, this protein undergoes hydroxylation, ubiquitination, and proteasomal degradation after translation under normal oxygen levels ${ }^{14}$. Because HIF1 $\alpha$ was induced by PAC-1 under normoxic conditions, we first examined the hydroxylation status of HIF1 $\alpha$ using specific antibodies targeting proline 564 (Pro564) hydroxylated HIF1 $\alpha$. Furthermore, treatment with the ubiquitin proteasome inhibitor MG132, which was used as a positive control because the ablation of proteasomal activity will result in the stabilization of hydroxylated HIF1 $\alpha$. Conversely, the iron chelator BP was used as a negative control because BP induces HIF1 $\alpha$ accumulation by sequestering iron and blocking the activity of prolyl hydroxylase domain protein 2 (PHD2), the enzyme responsible for HIF1 $\alpha$ hydroxylation. As shown in Fig. 3A, a concentration-dependent accumulation of hydroxylated HIF1 $\alpha$ was detected in MG132treated cells, whereas no fluorescent signal was detectable in PAC-1- and BP-treated cells. These findings suggest that the hydroxylation of HIF1 $\alpha$ was also blocked by PAC1. To further confirm these specific effects on hydroxylation, we investigated the impact of PAC-1 on HIF1 $\alpha$ - 


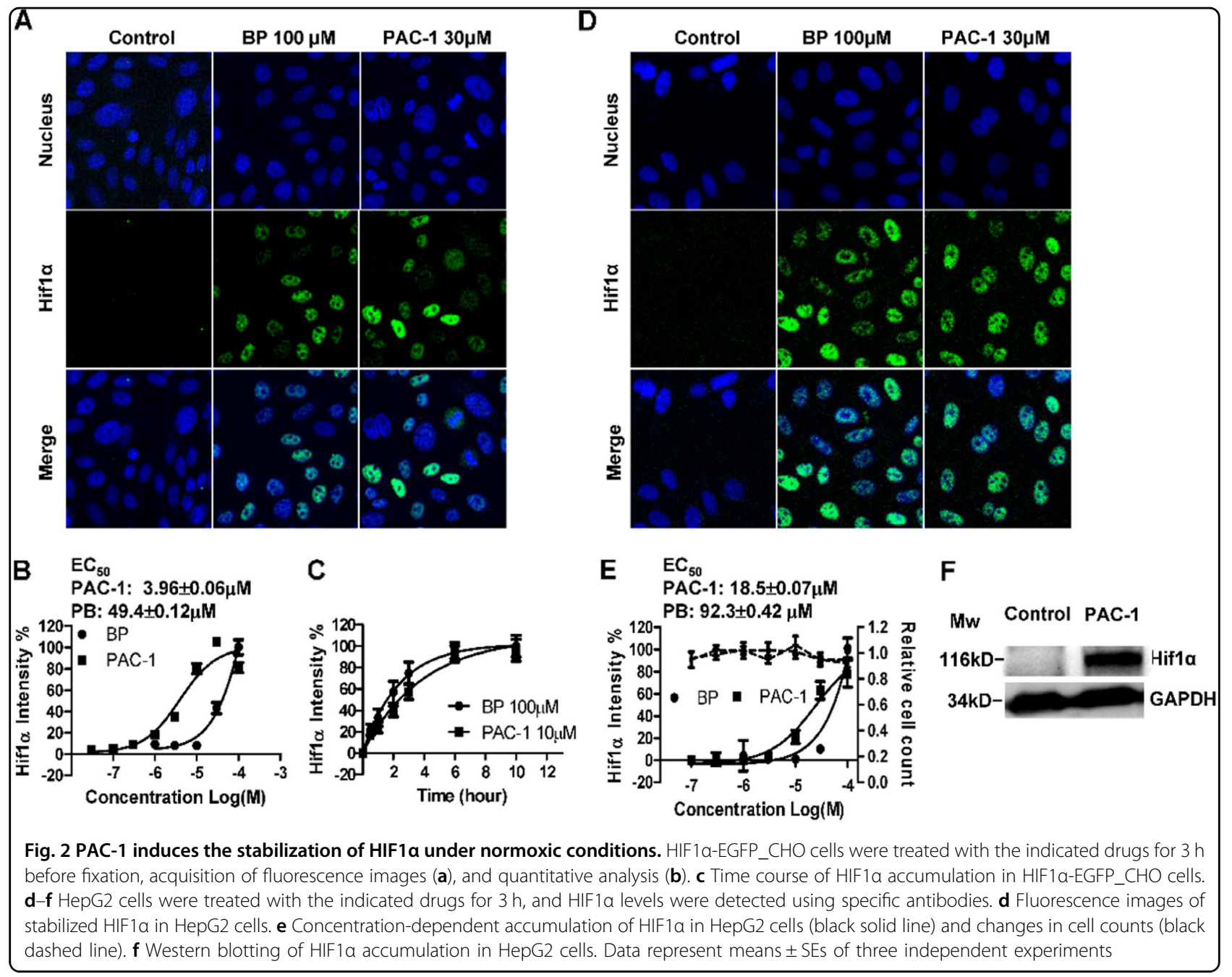

$\mathrm{OH}$ and HIF1 $\alpha$ respectively following treatment with MG132, as shown in Fig. 3B, b, notably, PAC-1 reduced HIF $1 \alpha-\mathrm{OH}$ levels in a concentration-dependent manner, but did not affect the cell counts. The minimum effective concentration was $1 \mu \mathrm{M}$, and the $\mathrm{EC}_{50}$ was $7.68 \pm 1.02$ $\mu \mathrm{M}$, which was lower than that required for HIF1 accumulation. Meanwhile, PAC-1 and BP also did not decreased HIF1 $\alpha$ level. These results indicate that PAC-1 specifically inhibits the hydroxylation of HIF1 $\alpha$.

Next, we examined the impact of PAC-1 on HIF1 $\alpha$ mRNA levels using qPCR. As shown in Fig. 3C, treatment with PAC-1 for up to $3 \mathrm{~h}$ did not affect HIF1 $\alpha$ mRNA levels, whereas a 6 -h treatment significantly decreased HIF $1 \alpha$ levels. Thus, PAC-1 induces HIF1 $\alpha$ accumulation by blocking the degradation process, rather than upregulating HIF1 $\alpha$ expression.

Finally, to test the functional activity of the accumulated HIF $1 \alpha$, we examined the expression levels of HIF1 $\alpha$ downstream target genes, i.e., VEGF-1 and EPO, by qPCR. Similar to hypoxic conditions $\left(1 \% \mathrm{O}_{2}\right)$ or the addition of the hypoxia-mimetic chemical BP, PAC-1 administration upregulated these two genes (Fig. 3D), suggesting that the PAC-1-induced HIF1 $\alpha$ was functional. The upregulation of other HIF1 $\alpha$ target genes was also observed (Supplement Fig. 1).

\section{PAC-1 induces the DNA damage response}

The induction of RAD51 focus formation in RAD51EGFP_SW480 cells following PAC-1 treatment was also observed in our screening assay. The RAD51 focusinducing activity of $0.1-100 \mu \mathrm{M}$ of PAC-1 was further assayed to confirm this finding. As shown in Fig. 4A, EGFPlabeled RAD51 foci formed in the nucleus in PAC-1-treated cells, whereas no foci formation was observed in the control group. A quantitative analysis of the fluorescence images for each treatment group revealed that the accumulation of RAD51 foci was concentration-dependent, with an $\mathrm{EC}_{50}$ of $25.1 \mu \mathrm{M}$ (Fig. 4A). Additionally, the percent cell loss also increased in a concentration-dependent manner but remained below 25\% (Fig. 4A). Because RAD51 is an 


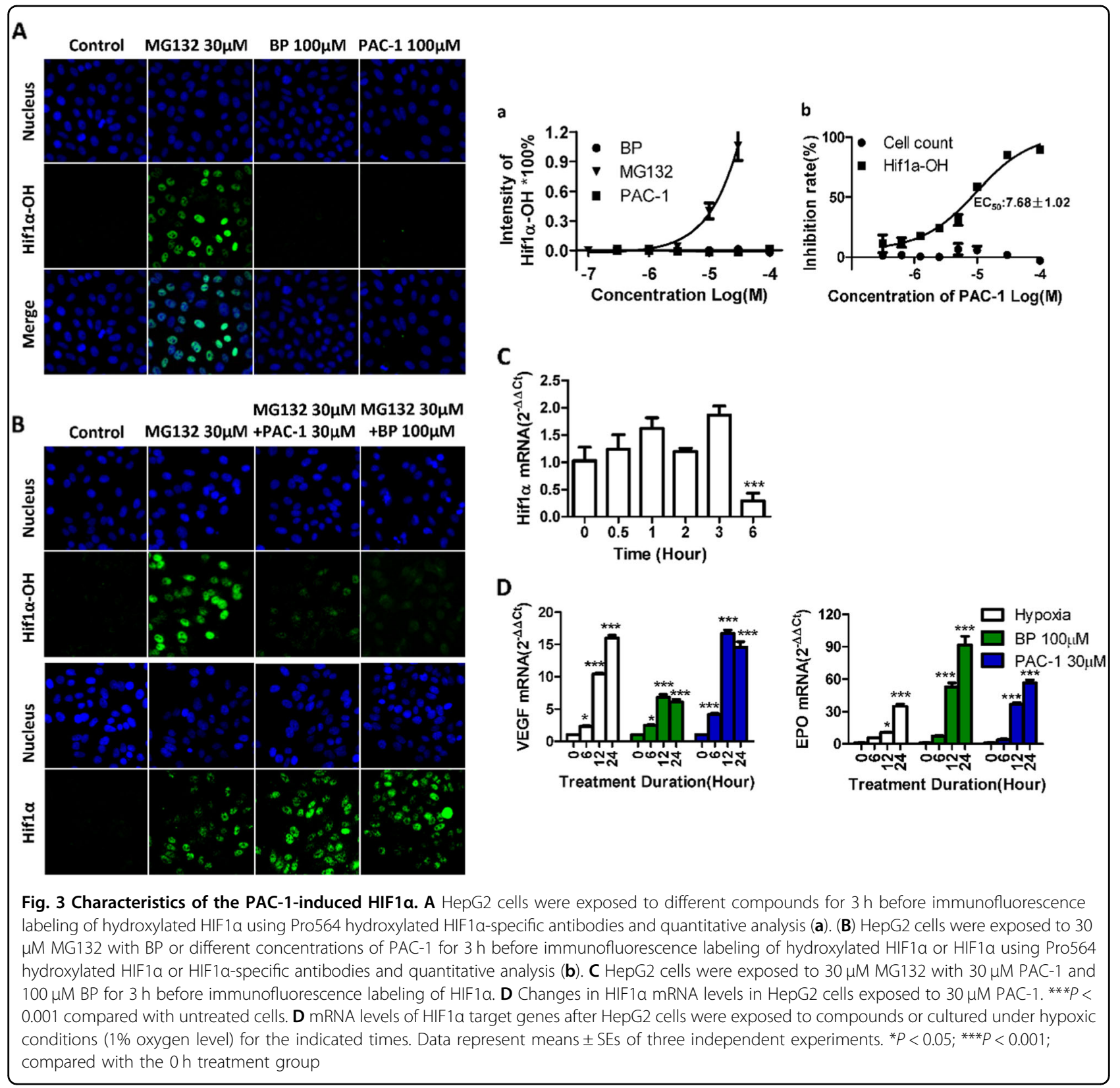

important enzyme in DNA damage repair, the formation of RAD51 foci following a $24 \mathrm{~h}$ PAC-1 treatment indicated the presence of DNA damage.

pH2AX, another sensitive marker of DNA damage ${ }^{15}$, was also found to be induced by PAC-1 in HepG2 cells and two other cancer cell lines (Bxpc-3 and MCF-7 cells) after a $24 \mathrm{~h}$ treatment (Fig. 4B, Supplement Fig. 2). The quantitative analysis showed that the induction of $\mathrm{pH} 2 \mathrm{AX}$ was also concentration-dependent (Fig. 4B, Supplement Fig. 2), with an $\mathrm{EC}_{50}$ of about $60.4 \mu \mathrm{M}$. Additionally, the cell count was decreased by about $40 \%$. These results suggest that PAC-1 indeed induces DNA damage and cytotoxicity.
To investigate the contribution of caspases to cellular DNA damage, we treated RAD51-EGFP_SW480 cells with PAC-1 and the pan-caspase inhibitor z-VAD-FMK. No changes in the formation of RAD51 foci were observed (Supplement figure S3), suggesting that the PAC-1 induced RAD51 foci formation is not dependent on caspase activation.

\section{PAC- 1 induces $G_{1} / S$ cell cycle arrest and blocks DNA synthesis in cancer cells}

DNA damage is often accompanied by cell cycle arrest. The effects of PAC- 1 on cell cycle progression were therefore examined using flow cytometry. We 

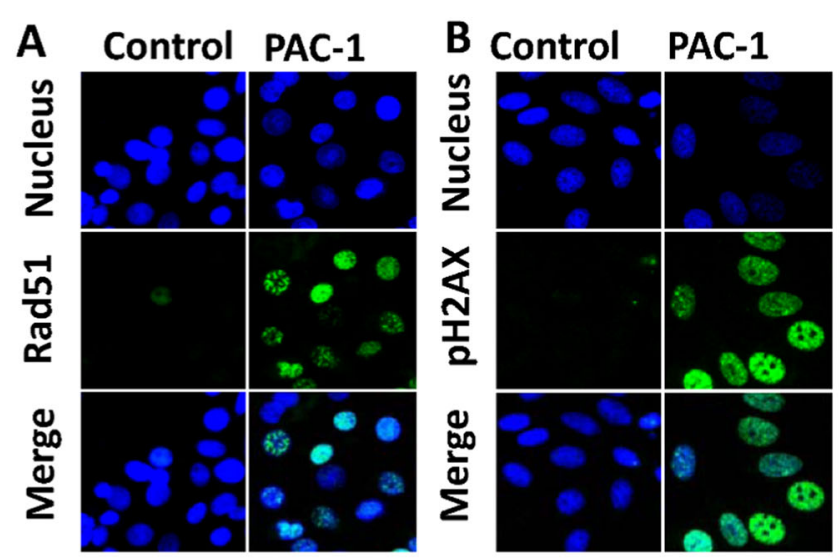

a

C

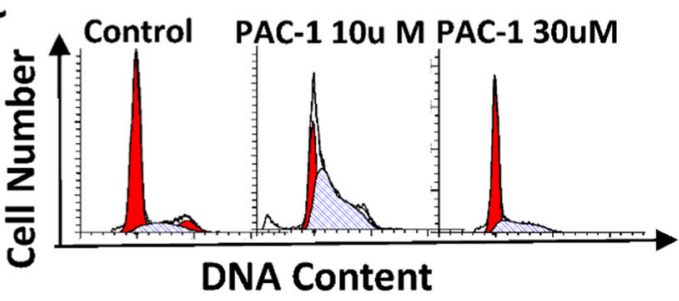

C
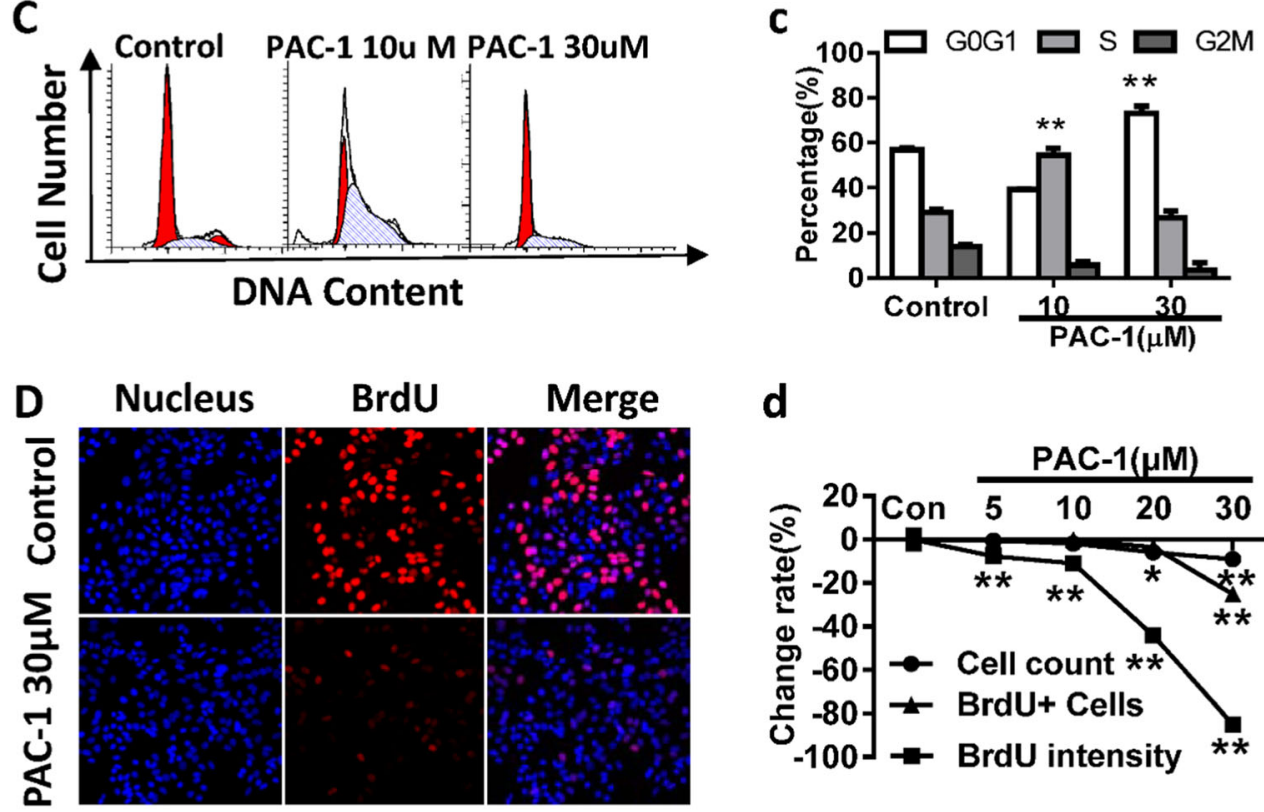

d
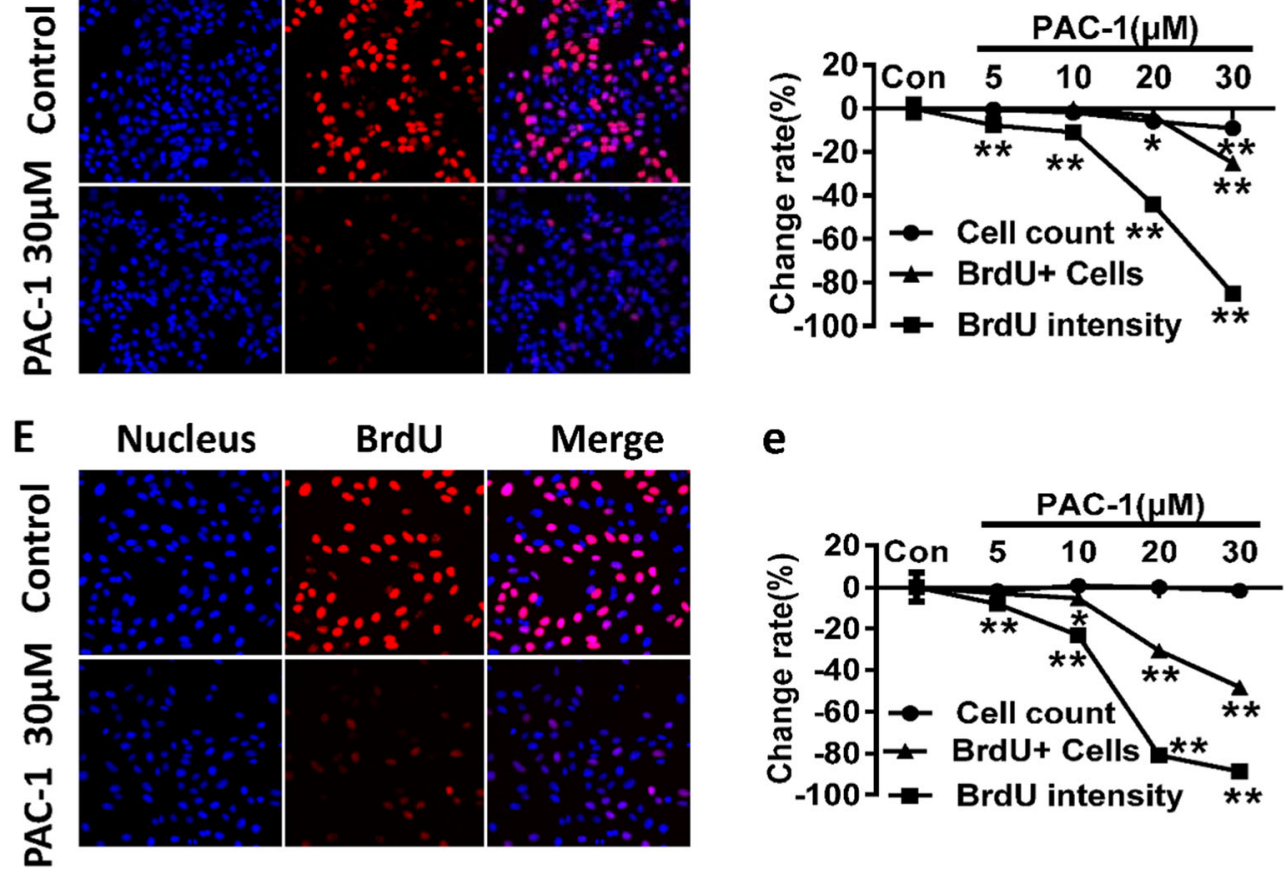

e

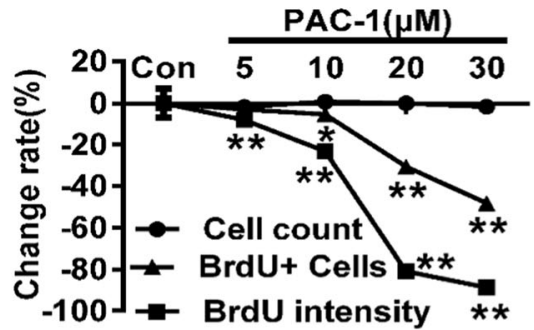

Fig. 4 PAC-1 induces the DNA damage response, arrests cell cycle progression and blocks DNA synthesis. A, a Fluorescence images of RAD51 foci and concentration-dependent increases in the total areas of RAD51 foci after RAD51-EGFP_SW480 cells were treated with PAC-1 for $24 \mathrm{~h}$. B, b Fluorescence images of accumulated pH2AX and the concentration-dependent increase in pH2AX intensity in HepG2 cells treated with PAC-1 for 24 h. C, c Cell cycle distribution in HepG2 cells after a 24-h PAC-1 treatment, as measured by flow cytometry. D, E BrdU incorporation status after PAC-1 exposure in HepG2 and U2OS cells. Cells were exposed to PAC-1 for $3 \mathrm{~h}$ before the addition of BrdU for another $3 \mathrm{~h}$. Cells undergoing DNA synthesis within the last $3 \mathrm{~h}$ were stained with a BrdU-specific fluorescent dye (red). Images were generated by merging the DAPI and BrdU channels. $\mathbf{d}$, e The $\mathrm{EC}_{50}$ was calculated using the data for BrdU intensity. Data represent means \pm SEs of three independent experiments. ${ }^{* *} P<0.01$ and ${ }^{*} P<0.05$ compared with the corresponding control 

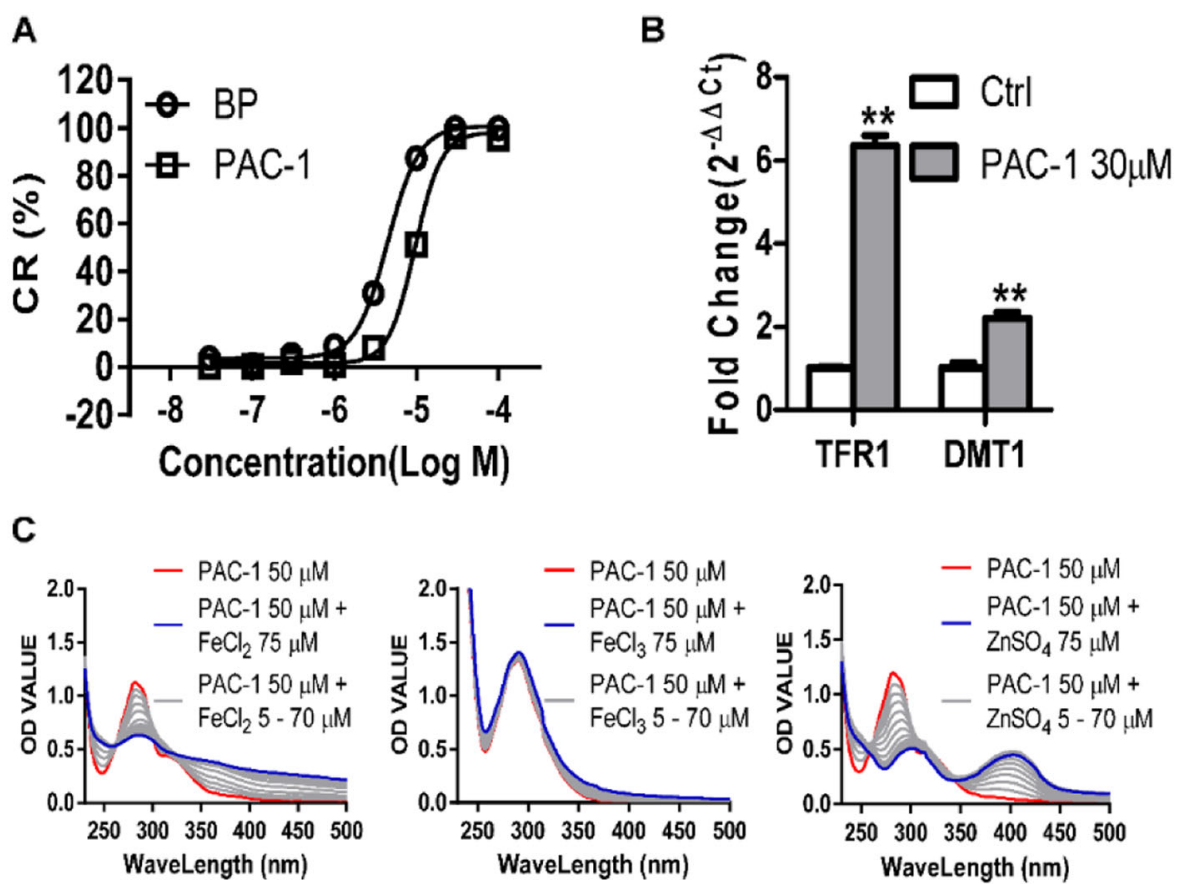

Fig. 5 Iron sequestration potential of PAC-1. (a) Determination of the iron sequestration activity of PAC-1 and the iron chelator BP in ferrozineiron-chelating assays. (b) Effects of PAC-1 treatment on TFR1 and DMT1 expression in HepG2 cells. (c) UV-Vis absorbance spectrum of changes induced by treatment with $50 \mu \mathrm{M} \mathrm{PAC}-1$ and $\mathrm{FeCl} 2$ or $\mathrm{ZnSO} 4$ titration (steps set as $5 \mu \mathrm{M}$ ). Data represent means \pm SEs of three independent experiments

observed that after a $24 \mathrm{~h}$ treatment with $10 \mu \mathrm{M}$ of PAC1 , the percentage of HepG2 cells in the $S$ phase was significantly increased, whereas treatment with $30 \mu \mathrm{M}$ of PAC-1 induced a significant $\mathrm{G}_{0} / \mathrm{G}_{1}$ phase arrest (Fig. 4C, c).

We then evaluated the effects of PAC-1 on DNA synthesis using BrdU incorporation assays in HepG2 and U2OS cells. A $3 \mathrm{~h}$ PAC-1 pre-exposure $(5-100 \mu \mathrm{M})$ decreased BrdU incorporation in a concentrationdependent manner, as shown by the reduced number of BrdU-positive cells and the intensity of BrdU-specific fluorescence (Fig. 4D, E). The $\mathrm{EC}_{50}$ values were $20.49 \pm$ 1.33 and $13.80 \pm 0.68 \mu \mathrm{M}$ for HepG2 and U2OS cells, respectively, but no reduction in the cell counts was observed (Fig. 4d, e). Thus, the inhibition of DNA synthesis by PAC-1 in both cell lines was independent of cytotoxicity.

\section{PAC-1 can sequester ferrous iron}

The accumulation of unhydroxylated HIF1 $\alpha$ after PAC-1 exposure suggested the inhibition of HIF1 $\alpha$ hydroxylation, which is catalyzed by PHD2 and is an iron (II)-dependent process ${ }^{16}$. The high degree of similarity between the PAC- 1 and BP HIF $1 \alpha$-induction profile (including its accumulation, hydroxylation status, and functional status), together with the finding that PAC-1 chelates zinc (II) led us to examine its iron (II) chelation ability. To address this, we performed ferrozine-iron (II) chelation assays ${ }^{17}$. Similar to the wellknown iron (II) chelator BP, PAC-1 showed a concentration-dependent iron (II) chelating activity (Fig. 5a). The zinc-chelating potential of PAC-1 was evaluated by monitoring changes in the PAC-1 ultraviolet-visible (UV-Vis) absorbance spectra in buffer A (50 mM HEPES, $100 \mathrm{mM} \mathrm{KNO}_{3}$, $\mathrm{pH}$ 7.2) in response to $\mathrm{ZnSO}_{4}$ titration 9 . Using the same system, we found that the titration of $\mathrm{FeCl}_{2}$ (but not $\mathrm{FeCl}_{3}$ ) also changed the $\mathrm{UV}-\mathrm{Vis}$ spectra of PAC-1 but that the effects of the $\mathrm{FeCl}_{2}$ titration were weaker than those of the $\mathrm{ZnSO}_{4}$ titration (Fig. 5c). Moreover, the mRNA levels for genes responsible for iron uptake, including transferrin receptor 1 (TFR1) and divalent metal transporter 1 (DMT1), were upregulated after $6 \mathrm{~h}$ of PAC-1 exposure (Fig. 5b), indicating that PAC-1 induces intracellular iron shortages.

Iron (II) supplementation reverses DNA damage and the HIF1a stabilization induced by PAC-1

To confirm that iron sequestration by PAC-1 was indeed responsible for HIF1 $\alpha$ stabilization, the effects of supplementation with additional iron were examined. HIF1 $\alpha$ was found to be downregulated in a concentrationdependent manner with increasing concentrations of $\mathrm{FeCl}_{2}$, whereas zinc supplementation did not show similar 


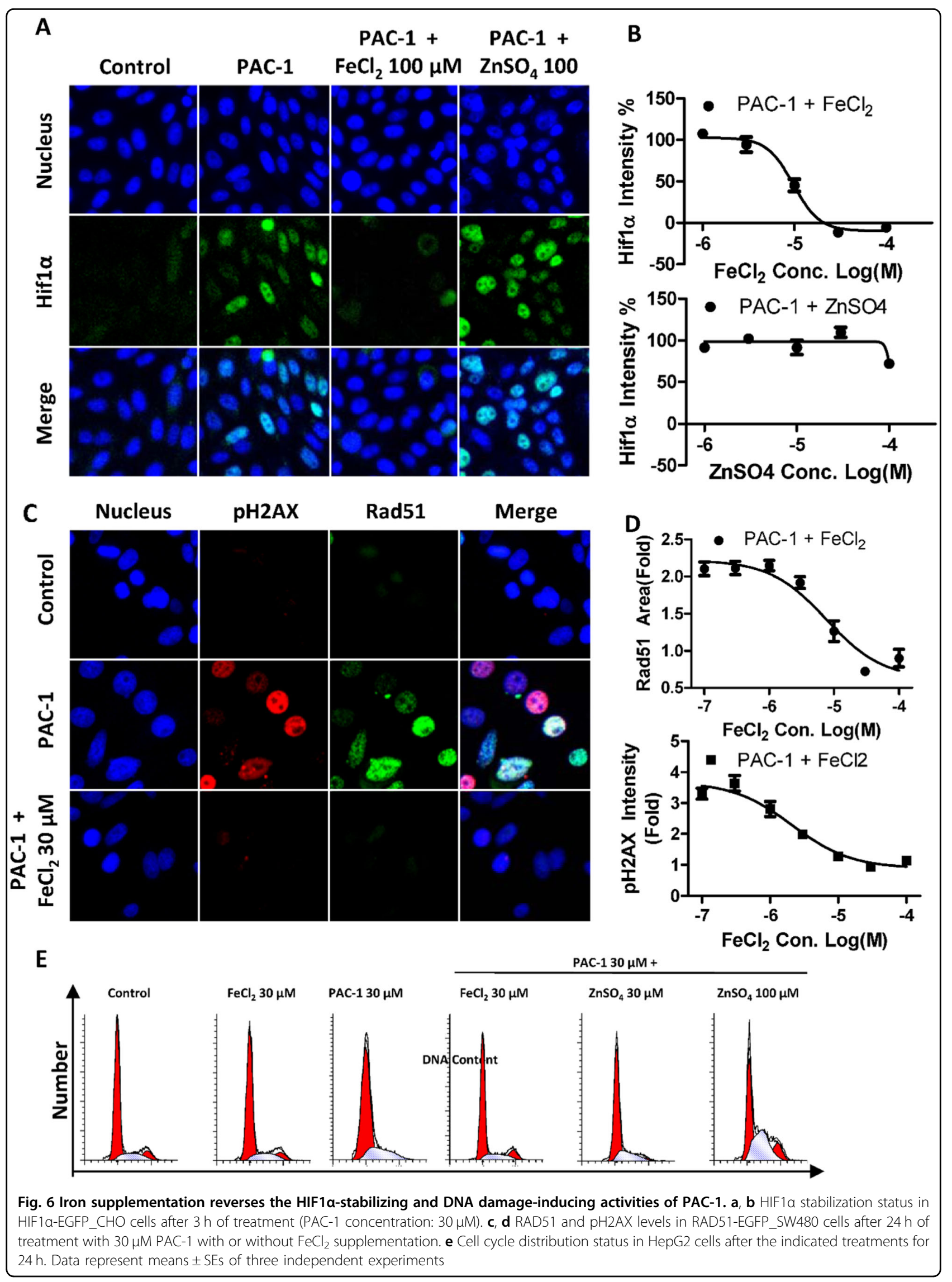



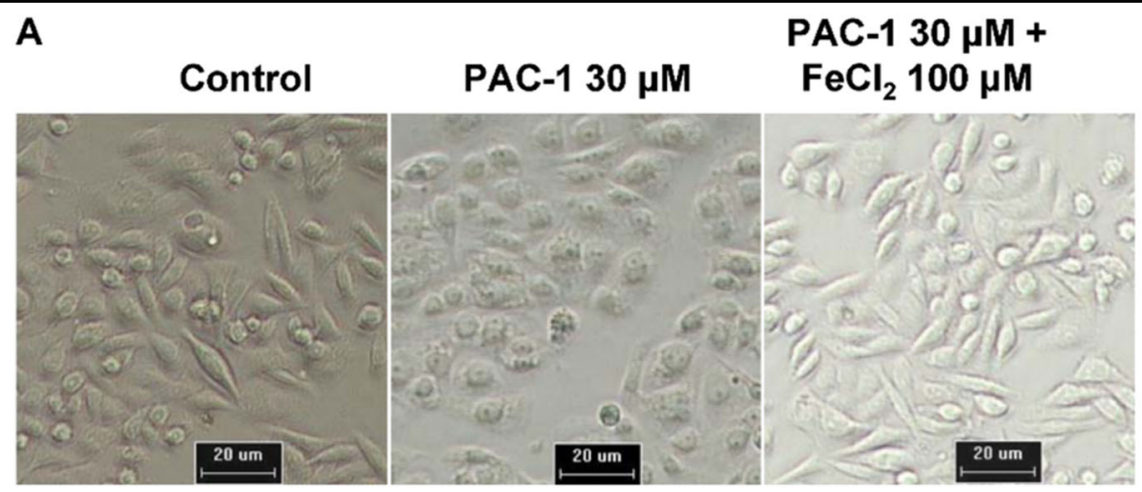

B
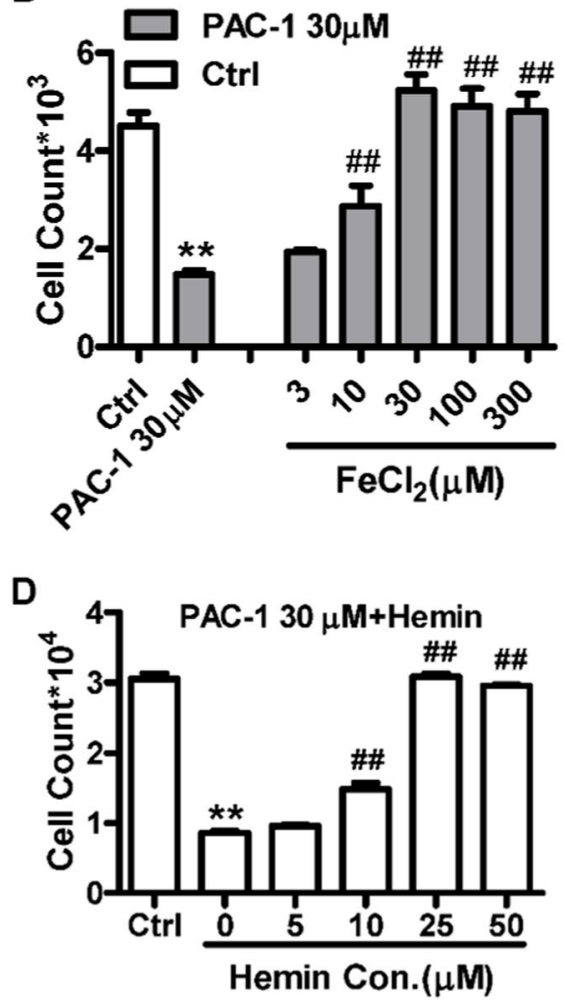

C

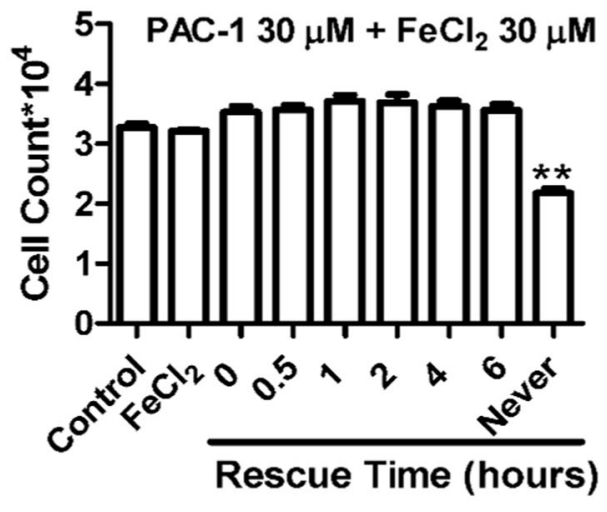

Fig. 7 Iron supplementation $(\mathbf{a}-\mathbf{c})$ and treatment with the iron donor hemin (d) reverses the antiproliferative activity of PAC-1. a HepG2 cell morphology after treatment with the indicated compounds for $24 \mathrm{~h}$. $\mathbf{b}$ Impact of $\mathrm{FeCl}_{2}$ on the PAC-1 antiproliferative activity. HepG2 cells were treated for $48 \mathrm{~h}$ before detection. ${ }^{* *} P<0.01$ compared with the control; ${ }^{\# \#} P<0.01$ compared with the PAC-1 $30 \mu \mathrm{M}$ group. $\mathbf{c}$ Effects of different FeCl 2 supplementation times on the PAC-1 antiproliferative activity. HepG2 cells were exposed to the indicated compounds and after various times, $30 \mu \mathrm{M}$ $\mathrm{FeCl}_{2}$ was added. $\mathbf{d}$ The cells were exposed to compounds for $24 \mathrm{~h}$ before detection. Data represent the means \pm SEs of three independent experiments. ${ }^{*} P<0.01$ compared with the control. \#\#P<0.01 compared with the PAC-1 $30 \mu \mathrm{M}$ group

effects (Fig. 6a, b). Moreover, the formation of RAD51 and $\mathrm{pH} 2 \mathrm{AX}$ foci was reversed in a concentration-dependent manner by $\mathrm{FeCl}_{2}$ (Fig. 6c, d), and the effects of PAC-1 on the $G_{1} / S$ cell cycle arrest were also abolished by supplementation with iron (II), but not zinc (Fig. 6e). These results suggest that the specific cellular responses described above are all due to the cellular iron shortage induced by PAC-1.
Iron (II) and hemin supplementation reverse the antiproliferative effects of PAC-1

To further confirm that the antitumor effects of PAC-1 were related to a cellular iron shortage, we also examined the effects of iron and an iron donor (hemin) on the antiproliferative activity of PAC-1. As shown in Fig. 7a, 24 $\mathrm{h}$ after the administration of PAC-1 changes in cell morphology were apparent, including bubble and granule 
formation. However, supplementation with $100 \mu \mathrm{M}$ of $\mathrm{FeCl}_{2}$ completely rescued these changes in cell morphology and reversed the antiproliferative effects of PAC- 1 in a concentration-dependent manner (Fig. 7b). Although hemin supplementation had similar effects, the effects of zinc supplementation were relatively weak compared with those of iron supplementation (Fig. 7d, Supplement Fig. 4). The same results were replicated in two other cancerous cell lines (Supplement Fig. 4). Moreover, iron rescue assays were performed by adding $\mathrm{FeCl}_{2}$ after PAC1 exposure, thereby guaranteeing the entry of the compound into the cells. As shown in Fig. $7 \mathrm{c}, \mathrm{FeCl}_{2}$ supplementation rescued the antiproliferative effects induced by the pre-exposure to PAC-1 for $6 \mathrm{~h}$, confirming that iron does reverse the intracellular activity of PAC-1. Taken together, these results suggest that iron sequestration plays a key role in mediating the activity of PAC-1.

\section{Discussion}

Off-target or multi-target effects are commonly observed for small-molecule drugs, and even for molecularly targeted drugs; therefore, a systematic screening of the activities of the lead or candidate compounds on multiple cellular pathways/targets is essential for drug discovery $^{18,19}$. During a comprehensive screening assay performed in our laboratory, PAC-1 was found to specifically induce cellular responses, including the stabilization of HIF $1 \alpha$ (under normoxic conditions) and the formation of RAD51 foci, in a concentration-dependent manner in EGFP-labeled reporter cell lines. Furthermore, the effects of PAC-1 on HIF1 $\alpha$ stabilization and DNA damage were validated in HepG2 cells and two other cancer cell lines, and the underlying mechanism was revealed.

HIF1 $\alpha$ is the main sensor and regulator of intracellular oxygen levels and undergoes hydroxylation, ubiquitination, and proteasome degradation after translation when oxygen levels are normal ${ }^{20}$. Low intracellular oxygen levels block HIF1 $\alpha$ degradation, thereby leading to the accumulation of the protein inside the cell. The accumulating HIF1 $\alpha$ then activates the transcription of genes responsible for angiogenesis, erythropoiesis, and glycolysis $^{21}$. The hydroxylation of HIF1 $\alpha$ is catalyzed by PHD2, an iron (II)- and 2-OG-dependent dioxygenase ${ }^{22}$. Iron (II) chelators, such as BP and deferrioxamine, are considered hypoxia mimetics because they induce HIF1 $\alpha$ stabilization by sequestering iron (II) and therefore interfere with PHD2 activity $^{23}$. In this study, a $3 \mathrm{~h}$ PAC-1 treatment induced the stabilization of HIF1 $\alpha$ in a concentrationdependent manner both in HIF1 $\alpha$-EGFP_CHO cells and HepG2 cells but did not cause any evident cytotoxicity. These results clearly indicate that the HIF $1 \alpha$-stabilizing effects of PAC-1 represent a specific and early cellular event, which occurs prior to cellular damage or death. Moreover, similar to the effect of the iron (II) chelator BP, the HIF1 $\alpha$ induced by PAC- 1 was functional and unhydroxylated on Pro564. Moreover, HIF1 $\alpha-\mathrm{OH}$ formation following MG132 treatment was inhibited by PAC-1, which also upregulated HIF $1 \alpha$ downstream target genes, including VEGF and EPO. Because PAC-1 is a potent inhibitor of HIF1 $\alpha-\mathrm{OH}$ formation and leads to changes in HIF1 $\alpha$ kinetics, hydroxylation, and activity similar to BP, while iron supplementation reverses the HIF $1 \alpha$-stabilizing activity of PAC-1, we concluded that PAC-1 may induce HIF $1 \alpha$ stabilization by sequestering iron and thus blocking HIF1 $\alpha$ hydroxylation.

PAC-1 is a metal ion-chelating agent ${ }^{24,25}$. The core mechanism through which PAC-1 activates procaspase-3 involves zinc chelation. The zinc-chelating activity of PAC-1 can be attributed to the ortho-hydroxy $N$-acyl functionality in its structure ${ }^{9,26}$, which was commonly believed to chelate bivalent metal ions, such as iron, zinc, and copper ${ }^{9,27,28}$. Moreover, this functionality forms a tridentate O,N,O donor set (Supplement Fig. 5, red), which is frequently found in common bioactive iron chelators, including $\mathrm{NIH}^{29}$. Therefore, the notion that PAC-1 may chelate iron (II) is reasonable. Our ferrozineiron (II) sequestration assays and the titration of $\mathrm{FeCl}_{2}$ (but not $\mathrm{FeCl}_{3}$ ) altered the UV-Vis absorbance spectra and support this hypothesis. Moreover, treatment with PAC-1 upregulated the levels of TFR1 and DMT1, two markers of intracellular iron shortages, in HepG2 cells. Importantly, iron chelators induce while zinc chelators contribute to HIF1 $\alpha$ stabilization $^{30}$. However, zinc chelation represses HIF1 $\alpha$ transcription by preventing the binding of the HIF1 coactivator p300, thereby triggering the nuclear accumulation of nonfunctional HIF1 $\alpha^{30,31}$. The upregulation of the VEGF and EPO HIF1 $\alpha$ target genes following PAC-1 treatment indicated that iron rather than zinc sequestration plays a dominant role in the PAC-1-induced HIF1 $\alpha$ accumulation.

The emergence of RAD51 foci was another important finding in our screening process. Because RAD51 foci are indicators of DNA damage, the DNA damage-inducing potential of PAC-1 was tested using another sensitive DNA damage marker, pH2AX. Interestingly, this marker also increased in a concentration-dependent manner following PAC-1 treatment, and was accompanied by cell death in HepG2, Bxpc-3, and MCF-7 cells. Furthermore, a DNA damage-related $G_{0} / G_{1} / S$ phase cell cycle arrest was also observed in HepG2 cells. Because PAC-1 was first reported as a precaspase- 3 agonist, we examined the contributions of caspases to DNA damage. The pancaspase inhibitor z-VAD-FMK failed to block the DNA damage induced by PAC-1, indicating that caspase- 3 activation was not the major contributor to the observed effects. Thus, our findings suggest that PAC-1 may be an iron (II) chelator and may inhibit the production of dNTPs in cancer cells by blocking the activity of 
ribonucleotide reductase (RNR). Indeed, RNR is also an iron-dependent enzyme and plays a critical role in regulating the total rate of DNA synthesis during cell division and DNA repair ${ }^{32-34}$, thereby inducing a $G_{1} / S$ cell cycle arrest $^{35}$. Consistent with the above observations, we found that PAC-1 blocked cellular DNA synthesis and that iron supplementation reversed the DNA damage and cell cycle arrest induced by PAC- 1 . More importantly, the PAC-1 $\mathrm{EC}_{50}$ value for the inhibition of DNA synthesis was clearly lower than that for the induction of DNA damage. These results confirmed the cause and effect relationship between DNA damage and iron sequestration. Therefore, the emergence of PAC-1-induced DNA damage may also be due to its iron (II) sequestration ability.

Both zinc and iron are vital trace elements, which are involved in various cellular activities and are essential for normal cellular function ${ }^{24,25}$. As an antitumor candidate, the antiproliferative effects of PAC-1 on HepG2, MCF-7, and BxPC-3 cancer cells were observed following $\mathrm{Fe}^{2+}$ and $\mathrm{Zn}^{2+}$ supplementation. Interestingly, iron supplementation reversed the antiproliferative effects of PAC-1 in a concentration-dependent manner and rescued the antiproliferative effects resulting from a $6 \mathrm{~h}$ pre-exposure to PAC-1. Moreover, the stabilization of HIF1 $\alpha$ and the $\mathrm{G}_{1} / \mathrm{S}$ cell cycle arrest were reversed by iron (II) rather than zinc supplementation, and the PAC-1-induced DNA damage was also reversed by iron supplementation. Therefore, iron (II) sequestration may play a more important role for PAC-1 activity than zinc chelation. These results could be explained by the observation that the labile iron pool, present in cells at about $1 \mu \mathrm{M}^{36}$, is much higher than that of zinc, which is present in cells at $5-1000 \mathrm{pM}^{37}$, even though the zinc-chelating ability of PAC-1 may be stronger at the molecular level. As described above, the hypoxic response induced by PAC-1 represents an early cellular stress response. While it does not elicit evident cytotoxicity at the time of detection, it can lead to oxidative damage and cause an imbalance in the mitochondrial membrane potential after $24 \mathrm{~h}$ of PAC1 treatment (Supplement Fig. 6). Additionally, the PAC-1induced DNA damage was accompanied by a significant decrease in cell counts. Furthermore, because RNR

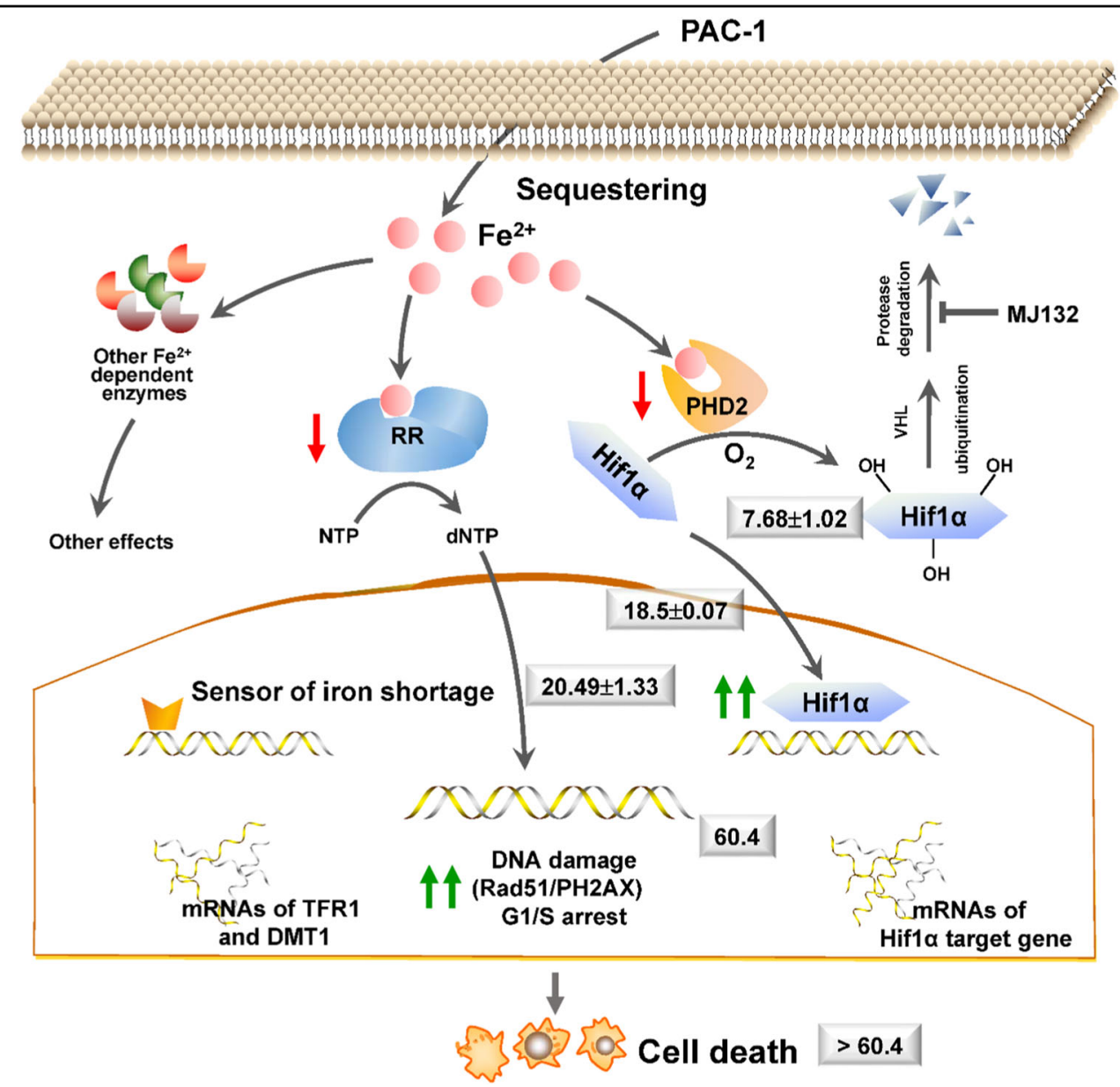

Fig. 8 Summary of the regulatory mechanism underlying the PAC-1 induction of HIF1a accumulation and DNA damage 
catalyzes the de novo synthesis of deoxyribonucleotides, which are precursors of DNA synthesis, it is essential for cell proliferation. Taken together, these results indicate that PAC-1 exerts its antiproliferative effects via the sequestration of cellular iron.

Iron chelators can block the activities of PHD2 and RNR, two well-known iron-dependent enzymes. A limitation of our study was the lack of availability of pure active protein, and thus the direct effects of PAC- 1 on the activities of PHD2 and RNR were not addressed here. However, the functionally related cellular responses, including the inhibition of MG132-induced HIF1 $\alpha-\mathrm{OH}$ formation, HIF $1 \alpha$ accumulation, DNA synthesis, DNA damage, and $G_{1} / S$ cell cycle arrest, which are commonly observed after the administration of iron chelators ${ }^{23,32,33}$, were all observed in PAC-1-treated cells. Additionally, the PAC-1 $\mathrm{EC}_{50}$ values for these responses gradually increased from upstream to downstream (Fig. 8). Moreover, the observation that supplementation with extra iron (II) abolished all of these effects further confirmed the cause-effect relationship between the iron-chelating and intracellular activities of PAC-1.

Taken together, our results showed for the first time that PAC-1 induces HIF1 $\alpha$ stabilization, DNA damage, and cell cycle arrest in cancer cells. Mechanistic analyses confirmed that PAC-1 exerted these activities mainly via the sequestration of cellular iron. Our findings provide important insights into the intracellular activity of PAC-1 and may facilitate the development of related anticancer compounds.

\section{Acknowledgements}

This work was supported by the National Science and Technology Major Project of the Ministry of Science and Technology of China (grant no. 2012ZX09301-001 and 2012ZX09301-003), the National Natural Science Foundation of China (grant no. 81430090 and 81773790), and partially supported by the project of State Key Laboratory of Functions and Applications of Medicinal Plants, Guizhou Medical University (FAMP201708K)

\section{Author details}

${ }^{1}$ Beijing Institute of Pharmacology and Toxicology, State Key Laboratory of Toxicology and Medical Countermeasures, Beijing 100850, China. ${ }^{2}$ State Key Laboratory of Functions and Applications of Medicinal Plants, Guizhou Medical University, Guiyang 550014, China. ${ }^{3}$ Key Laboratory of Cell Proliferation and Regulation Biology, Beijing Normal University, Beijing 100875, China

\section{Conflict of interest}

The authors declare that they have no conflict of interest.

\section{Publisher's note}

Springer Nature remains neutral with regard to jurisdictional claims in published maps and institutional affiliations.

Supplementary Information accompanies this paper at (https://doi.org/ 10.1038/s41419-018-1038-3).

Received: 10 May 2018 Revised: 4 September 2018 Accepted: 6 September 2018

Published online: 04 October 2018

\section{References}

1. Lowe, S. W. \& Lin, A. W. Apoptosis in cancer. Carcinogenesis 21, 485-495 (2000).

2. Putt, K. S. et al. Small-molecule activation of procaspase-3 to caspase-3 as a personalized anticancer strategy. Nat. Chem. Biol. 2, 543-550 (2006).

3. Hsu, D. C. et al. Parallel synthesis and biological evaluation of 837 analogues of procaspase-activating compound 1 (PAC-1). ACS Comb. Sci. 14, 44-50 (2012).

4. Peterson, Q. P. et al. Discovery and canine preclinical assessment of a nontoxic procaspase-3-activating compound. Cancer Res. 70, 7232-7241 (2010).

5. Wolan, D. W., Zorn, J. A., Gray, D. C. \& Wells, J. A. Small-molecule activators of a proenzyme. Science 326, 853-858 (2009).

6. Wang, F. et al. A novel small-molecule activator of procaspase-3 induces apoptosis in cancer cells and reduces tumor growth in human breast, liver and gallbladder cancer xenografts. Mol. Oncol. 8, 1640-1652 (2014).

7. Strand, O. A. et al. Synthesis and initial in vitro biological evaluation of two new zinc-chelating compounds: comparison with TPEN and PAC-1. Bioorg. Med. Chem. 21, 5175-5181 (2013).

8. Denault, J. B. et al. Small molecules not direct activators of caspases. Nat. Chem. Biol. 3, 519 (2007). author reply 520.

9. Peterson, Q. P. et al. PAC-1 activates procaspase-3 in vitro through relief of zinc-mediated inhibition. J. Mol. Biol. 388, 144-158 (2009).

10. Long, L. et al. Dynamic cytotoxic profiles of sulfur mustard in human dermal cells determined with multiparametric high-content analysis. Toxicol. Res. 5, 583-593 (2016).

11. Wang, C., Wang, L. \& Zhao, C. Development of a plate-based assay for highcontent analysis of individual untethered non-adherent cells. Comb. Chem. High Throughput Screen. 14, 583-589 (2011).

12. Meng, J. et al. Combination treatment with MEK and AKT inhibitors is more effective than each drug alone in human non-small cell lung cancer in vitro and in vivo. PLOS ONE 5, e14124 (2010).

13. Chen, W. et al. Novel PPAR pan agonist, ZBH ameliorates hyperlipidemia and insulin resistance in high fat diet induced hyperlipidemic hamster. PLOS ONE $\mathbf{9}$, e96056 (2014).

14. Wenger, R. H., Stiehl, D. P. \& Camenisch, G. Integration of oxygen signaling at the consensus HRE. Sci. STKE 2005, re12 (2005).

15. Bonner, W. M. et al. GammaH2AX and cancer. Nat. Rev. Cancer 8, 957-967 (2008).

16. To, K. K. \& Huang, L. E. Suppression of hypoxia-inducible factor 1alpha (HIF1alpha) transcriptional activity by the HIF prolyl hydroxylase EGLN1. J. Biol. Chem. 280, 38102-38107 (2005).

17. Jeong, J. B., De Lumen, B. O. \& Jeong, H. J. Lunasin peptide purified from Solanum nigrum $L$. protects DNA from oxidative damage by suppressing the generation of hydroxyl radical via blocking fenton reaction. Cancer Lett. 293, 58-64 (2010).

18. Bowes, J. et al. Reducing safety-related drug attrition: the use of in vitro pharmacological profiling. Nat. Rev. Drug Discov. 11, 909-922 (2012).

19. Dahlin, J. L. \& Nelson, K. M. Assay interference and off-target liabilities of reported histone acetyltransferase inhibitors. Nat. Commun. 8, 1527 (2017).

20. Semenza, G. L. Hypoxia-inducible factor 1 (HIF-1) pathway. Sci. STKE 2007, cm8 (2007).

21. Masson, N. \& Ratcliffe, P. J. HIF prolyl and asparaginyl hydroxylases in the biological response tointracellular O2 levels. J. Cell Sci. 116, 3041 (2003).

22. Mcneill, L. A. et al. Hypoxia-inducible factor prolyl hydroxylase 2 has a high affinity for ferrous iron and 2-oxoglutarate. Mol. Biosyst. 1, 321-324 (2005).

23. Ono, S. et al. Effect of Deferoxamine-activated Hypoxia Inducible Factor-1 on the Brainstem Following Subarachnoid Haemorrhage (Springer, Vienna, 2008).

24. Baell, J. \& Walters, M. A. Chemistry: chemical con artists foil drug discovery. Nature 513, 481-483 (2014).

25. Frye, S. V. et al. Tackling reproducibility in academic preclinical drug discovery. Nat. Rev. Drug Discov. 14, 733 (2015).

26. Peterson, Q. P. et al. Procaspase-3 activation as an anti-cancer strategy: structure-activity relationship of procaspase-activating compound 1 (PAC-1) and its cellular co-localization with caspase-3. J. Med. Chem. 52, 5721-5731 (2009).

27. Charkoudian, L. K. \& Franz, K. J. Fe(III)-coordination properties of neuromelanin components: 5,6-dihydroxyindole and 5,6-dihydroxyindole-2-carboxylic acid. Inorg. Chem. 45, 3657-3664 (2006).

28. Charkoudian, L. K., Pham, D. M. \& Franz, K. J. A pro-chelator triggered by hydrogen peroxide inhibits iron-promoted hydroxyl radical formation. J. Am. Chem. Soc. 128, 12424-12425 (2006). 
29. Gautam, R., Akam, E. A., Astashkin, A. V., Loughrey, J. J. \& Tomat, E. Sirtuin inhibitor sirtinol is an intracellular iron chelator. Chem. Commun. (Camb.). $\mathbf{5 1}$ 5104-5107 (2015).

30. Choi, S. M., Choi, K. O., Lee, N., Oh, M. \& Park, H. The zinc chelator, N,N,N',N'tetrakis (2-pyridylmethyl) ethylenediamine, increases the level of nonfunctional HIF-1alpha protein in normoxic cells. Biochem. Biophys. Res. Commun. 343 1002-1008 (2006).

31. Cook, K. M. et al. Epidithiodiketopiperazines block the interaction between hypoxia-inducible factor-1alpha (HIF-1alpha) and p300 by a zinc ejection mechanism. J. Biol. Chem. 284, 26831-26838 (2009).

32. Furukawa, T., Naitoh, Y., Kohno, H., Tokunaga, R. \& Taketani, S. Iron deprivation decreases ribonucleotide reductase activity and DNA synthesis. Life Sci. 50, 2059-2065 (1992).
33. Le, N. T. V. \& Richardson, D. R. The role of iron in cell cycle progression and the proliferation of neoplastic cells. Biochim. Biophys. Acta 1603, 31-46 (2002).

34. Shao, J., Zhou, B., Chu, B. \& Yen, Y. Ribonucleotide reductase inhibitors and future drug design. Curr. Cancer Drug Targets 6, 409-431 (2006).

35. Hoyes, K. P., Hider, R. C. \& Porter, J. B. Cell cycle synchronization and growth inhibition by 3-hydroxypyridin-4-one iron chelators in leukemia cell lines. Cancer Res. 52, 4591-4599 (1992)

36. ElX Hammas, K. Book Review: Iron Deficiency and Overload: From Basic Biology to Clinical Medicine. Nutrition in Clinical Practice 25, 562-562 (2010).

37. Qin, Y., Dittmer, P. J., Park, J. G., Jansen, K. B. \& Palmer, A. E. Measuring steadystate and dynamic endoplasmic reticulum and Golgi Zn2 + with genetically encoded sensors. Proc. Natl. Acad. Sci. USA 108, 7351-7356 (2011). 